\title{
Chestnut and lemon balm based ingredients as natural preserving agents of the nutritional profile in matured "Serra da Estrela" cheese
}

\author{
Márcio Carocho a,b, João C.M. Barreira ${ }^{\mathrm{a}}$, Albino Bento ${ }^{\mathrm{a}}$, Virginia Fernández-Ruiz ${ }^{\mathrm{b}}$, Patricia Morales ${ }^{\mathrm{b}}$, \\ Isabel C.F.R. Ferreira ${ }^{\mathrm{a}, *}$ \\ ${ }^{a}$ Mountain Research Centre (CIMO), ESA, Polytechnic Institute of Bragança, Campus de Santa Apolónia 1172, $5301-855$ Bragança, Portugal \\ ${ }^{\mathrm{b}}$ Department of Bromatology II, Faculty of Pharmacy, Complutense University of Madrid, Plaza Ramón y Cajal, s/n., 28040 Madrid, Spain
}

\section{A R T I C L E I N F O}

\section{Article history:}

Received 24 November 2015

Received in revised form 27 January 2016

Accepted 22 February 2016

Available online 23 February 2016

\section{Keywords:}

Castanea sativa Mill.

Melissa officinalis L.

Nutritional composition

Fatty acids

Cheese

\begin{abstract}
A B S T R A C T
Chestnut flowers, lemon balm plants and their decoctions were incorporated into "Serra da Estrela" cheese, to assess their potential to preserve its nutritional properties and provide new foodstuffs. The analyses were carried out after the normal ripening period of 1 month and after 6 months of storage. The most abundant nutrients were proteins and fats. The most abundant minerals were $\mathrm{Ca}$ and $\mathrm{Na}$, while C16:0 and C18:1 were the main fatty acids. Saturated fatty acids were the most abundant, followed by the monounsaturated. Moisture seemed to be lower in the samples with the plants incorporated. The dried plants, when incorporated, seemed to be more efficient as preservers then the decoctions, although these better preserved the proteins. These plants can be regarded as promising natural preservers in foodstuffs cheese, given the preservation of key parameters and the slight impact on the nutritional value.
\end{abstract}

(C) 2016 Elsevier Ltd. All rights reserved.

\section{Introduction}

The ever-growing food industry is avid for innovations in foodstuffs in order to create new markets and stimulate purchasing. For a few years, consumers have been gaining interest in healthy, functional and bioactive foodstuffs, which are prepared with the least additives possible, and preferably with natural ingredients (Carocho, Barreiro, Morales, \& Ferreira, 2014). This has happened due to the concern about consumers' health and a healthier way of living. To adapt to these behavioral changes in consumption, the food industry is searching for innovative, healthy and cheap food products. Plants are an endless resource of bioactive compounds and their use in the diet is increasing, especially in developed countries. Among the plants, flowers are starting to be used as food for their appearance, taste and beneficial properties (Mlcek \& Rop, 2011). Chestnut flowers (Castanea sativa Mill.) have an outstanding antioxidant capacity, also displaying antimicrobial and antitumor effects. This activity could be related to their phenolic fraction, which could also contribute to other described medicinal effects, namely as a mucolytic, antispasmodic and antidysenteric treatment (Carocho, Barros, et al., 2014; Carocho, Calhelha, et al., 2014; Neves, Matos, Moutinho, Queiroz, \& Gomes, 2009). Other plants, like lemon balm (Melissa officinalis

\footnotetext{
* Corresponding author.

E-mail address: iferreira@ipb.pt (I.C.F.R. Ferreira).
}

L.), also display many medicinal effects, especially when consumed as an infusion or decoction. These effects encompass expectorant, digestion relief, ease of headaches and rheumatism, prevention of neurodegenerative diseases, antitumor, antiproliferative, anticholinesterase, antioxidant and anti-Alzheimer properties among many others (Barros et al., 2013; Carnat, Carnat, Fraisse, \& Lamaison, 1998; Carocho, Barros, Calhelha, et al., 2015; Martins et al., 2012; Pereira et al., 2014; Salah \& Jäger, 2005). Moreover, both these plants could act as antioxidants and antimicrobials in foodstuffs, acting as natural additives within the foodstuff, as well as aiding health benefits to potential consumers. The food industry is spending increasing efforts to find natural compounds and/or plant extracts to be incorporated into food in order to substitute chemical additives in its formulations, mainly due to controversies related to some of these compounds that could involve them in undesirable effects towards human health (Carocho, Morales, \& Ferreira, 2015). Although the incorporation of plant extracts in foodstuffs has been carried out previously (McCarthy, Kerry, Kerry, Lynch, \& Buckey, 2001; Reihani, Tan, Huda, \& Easa, 2014; Stojković et al., 2013), including by our research group (Carocho, Barreira, Antonio, et al., 2015; Carocho, Barreira, Barros, et al., 2015; Carocho, Barreira, Bento, Morales, \& Ferreira, 2014), it is the first time that is done in "Serra da Estrela" cheese in order to determine the variation of the nutritional profile with storage time. Previously, these same plants were used to functionalize "Serra da Estrela" cheese, bringing them antioxidant activity (Carocho, 
Barreira, Antonio, et al., 2015). This Portuguese delicacy is the most famous cheese produced in the country, and is appreciated worldwide. It is only manufactured with raw ewe's milk, salt and milk thistle flower for coagulation, and it is preferentially consumed as a soft cheese, with an average maturation of 1 month, although some consumers prefer to consume it as a hard cheese after at least 6 months of storage. Despite some published studies on the "Serra da Estrela" cheese, that focus mainly on the microbial flora in the cheese, as well as the changes in some nutrients during ripening (Dahl, Tavaria, \& Malcata, 2000; Macedo, Tavares, \& Malcata, 2004; Partidário, Barbosa, \& Boas, 1998; Tavaria, Franco, Carballo, \& Malcata, 2003; Tavaria, Reis, \& Malcata, 2006), the present work evaluates the effects of natural additives (chestnut flowers, lemon balm dry material and their decoctions) on the nutritional properties of cheese during its maturation.

\section{Materials and methods}

\subsection{Plant material and natural additives}

Chestnut flowers, C. sativa Mill., belonging to the cultivars Judia and Longal were obtained in June 2013 from Oleiros in Bragança, Portugal ( $\left.41^{\circ} 51^{\prime} 02^{\prime \prime} \mathrm{N}, 6^{\circ} 49^{\prime} 54^{\prime \prime} \mathrm{W}\right)$. After lyophilisation (FreeZone 4.5 , Labconco, Kansas, USA) they were milled down to a fine powder. The decoction procedure was previously described by Carocho, Barreira, Antonio, et al. (2015). Briefly, $5 \mathrm{~g}$ of the chestnut flower powder was added to $1 \mathrm{~L}$ of cold water and heated until it reached its boiling point; it was maintained at this temperature for 5 min. Then, the heat was turned off and left for another $5 \mathrm{~min}$. After filtration through a Whatman $\mathrm{N}^{\circ} 4$ filter the decoction was further frozen and lyophilized. The same procedure was carried out for dried lemon balm, M. officinalis L., stems and leaves, which were provided by the company "Mais Ervas" (Alfândega da Fé, Portugal). Both dry material and lyophilized decoctions of chestnut flowers and lemon balm were used as natural additives that were incorporated in "Serra da Estrela" cheese.

\subsection{Cheese production}

The cheese samples used in the assays were produced in the certified cheese factory "Queijos Casa Matias", based in Seia, Portugal. The ewe milk (breed Churra Mondegueira) was collected in the morning and brought to the facility under a constant temperature of $5{ }^{\circ} \mathrm{C}$ and a $\mathrm{pH}$ of 6.88 . The milk was placed in an automated mixer reservoir, which was attached to an automated cheese producing machine. Salt $(30 \mathrm{~g} / \mathrm{L}$ of milk) and milk thistle extract (Cynara cardunculus $\mathrm{L}$.) $(0.4 \mathrm{~g} / \mathrm{L}$ of milk) were added to the milk and left to coagulate. After the milk coagulation $(1 \mathrm{~h})$, the cheese was collected from the reservoir and placed in molds, which were slightly pressed to remove the serum. Then, the molds are placed in a conveyor belt to be collected by personnel for a second pressing at a higher pressure. After $2 \mathrm{~h}$ of a second pressing the cheese is embalmed with a cloth around its sides to maintain its format and placed in maturing chambers. The first chamber had a relative humidity of $95-100 \%$ and a constant temperature ranging from 7 to $9{ }^{\circ} \mathrm{C}$. The cheeses were kept here for 15 days, after which they were transferred into the second chamber, kept between $80-82 \%$ of relative humidity and $11-13^{\circ} \mathrm{C}$ for another 15 days. The cheeses were washed with water every second week to remove exterior contamination.

\subsection{Incorporation of the natural additives}

The dried plants and their respective decoctions were added to the cheese between the two pressings, by manually mashing them, adding the natural additives and replacing them into the molds for the second pressing. After incorporation, the cheese followed all the normal steps of production. Five lots of cheese were produced: 1 - cheese samples with dried chestnut flowers incorporated, 2 cheese samples with dried lemon balm incorporated, 3 - cheese samples with decoction of chestnut flower incorporated, 4 - cheese samples with decoction of lemon balm incorporated, and 5 cheese with no incorporation, control lot. In order to determine the quantity of dried plant or decoction to be added to the cheese, the $\mathrm{EC}_{50}$ value of the DPPH (2,2-diphenyl-1-picrylhydrazyl) antioxidant assay was used. The $\mathrm{EC}_{50}$ of chestnut flower was $99.47 \mu \mathrm{g} /$ $\mathrm{mL}$, as reported previously (Carocho, Barreira, et al., 2014). This value was adjusted to the quantity of milk used for each cheese, resulting in the addition on $248 \mathrm{mg}$ of chestnut decoction per cheese. For the lot with dried flowers incorporated, the decoction extraction yield (31\%) was used. Therefore, 31\% corresponded to the $\mathrm{EC}_{50}$ of the decoction $(99.47 \mu \mathrm{g} / \mathrm{mL})$, and $319 \mu \mathrm{g} / \mathrm{mL}$ corresponded to $100 \%$. Once again, by adjusting the amount of milk used per cheese, $799 \mathrm{mg}$ of dried flower was added to each one. For the other natural additive (lemon balm), the same calculations were used ( $\mathrm{EC}_{50}-60 \mu \mathrm{g} / \mathrm{mL}$; yield $38.9 \%$ ), thus, $380 \mathrm{mg}$ of plant decoction per cheese for one lot, and $368 \mathrm{mg}$ of dried plant per cheese for the other lot (Carocho, Barros, Calhelha, et al., 2015).

After the maturation period ( 1 month), all the cheese samples were collected from the company and brought to the laboratory under controlled temperatures. Two cheeses of each lot were immediately processed, being peeled, cut into small cubes, frozen, lyophilized and milled down, while the other two cheeses from the lot were kept in refrigeration $\left(5^{\circ} \mathrm{C}\right)$ during a storage period of 6 months and then processed in the same manner.

\subsection{Standards and reagents used in the laboratorial analyses}

Micro (Fe, $\mathrm{Cu}, \mathrm{Mn}$ and $\mathrm{Zn}$ ) and macroelements (Ca, Mg, Na and K) standards ( $>99 \%$ purity), as well as $\mathrm{LaCl}_{2}$ and $\mathrm{CsCl}$ (>99\% purity) were purchased from Merck (Darmstadt, Germany). The fatty acids methyl ester (FAME) reference standard mixture 37 (standard 47885-U) was purchased from Sigma (St. Louis, MO, USA), as also other individual fatty acid isomers. Sulfuric and hydrochloric acids were obtained from Fisher Scientific (Waltham, MA, USA) and nitric acid was purchased from Sigma (St. Louis, MO, USA). Water was treated in a Milli-Q water purification system (TGI Pure Water Systems, Greenville, SC, USA).

\subsection{Evaluation of nutritional profile}

\subsubsection{Proximate composition}

The proximate composition was calculated based on moisture, proteins, fat and ash, relying on the official AOAC procedures (AOAC, 2012). Moisture was determined by desiccation at constant weight at $100 \pm 2{ }^{\circ} \mathrm{C}$. Total protein content $(N \times 6.38)$ was calculated as nitrogen content by the Kjeldahl method, while crude fat relied on the extraction of dried samples with petroleum ether using a Soxhlet apparatus. The ash content was determined by incineration at $550 \pm 15{ }^{\circ} \mathrm{C}$. Finally, carbohydrates were calculated by difference, but due to not being detected, they were considered zero.

\subsubsection{Fatty acids}

Fatty acids were determined by gas chromatography. The equipment consisted of a gas chromatograph (GC) (DANI 1000, Contone, Switzerland) coupled to a split/splitless injector and a flame ionization detector (FID) as previously described (Barros, Oliveira, Carvalho, \& Ferreira, 2010). The identification was carried out by comparing the relative retention times of the fatty acids methyl esters of the samples (FAME) to commercial standards. 
The quantification was achieved through CSW 1.7 (DataApex 1.7, Prague, Czech Republic). The results were expresses in relative percentage of each fatty acid.

\subsubsection{Mineral composition: macro and microelements}

The procedure for the total mineral content followed the 930.05 AOAC methodology. The samples were subject to incineration at $550 \pm 15^{\circ} \mathrm{C}$, with the resulting residue being dissolved in $\mathrm{HCl}$ and $\mathrm{HNO}_{3}$, and finally adjusting the volume with distilled water. Microelements ( $\mathrm{Fe}, \mathrm{Zn}$ and $\mathrm{Cu}$ ) were measured directly, while the macroelements ( $\mathrm{Ca}, \mathrm{Mg}, \mathrm{Na}$ and $\mathrm{K}$ ) were diluted at a 1:10 ratio reason to avoid interferences. The methodology followed was previously reported by Fernández-Ruiz, Olives, Cámara, Sánchez-Mata, and Torija (2011), in which Analyst 200 Perkin Elmer (Perkin Elmer, Waltham, MA, USA) atomic absorption spectroscope (AAS) with air/acetylene flame was used. The absorbances were compared with responses $>99.9 \%$ pure analytical standard solutions for AAS made with $\mathrm{Fe}\left(\mathrm{NO}_{3}\right)_{3}, \mathrm{Zn}\left(\mathrm{NO}_{3}\right)_{2}, \mathrm{NaCl}, \mathrm{KCl}, \mathrm{CaCO}_{3}$ and $\mathrm{Mg}$ band. The results were expressed in $\mathrm{mg} / 100 \mathrm{~g}$ of fresh weight.

\subsection{Statistical analysis}

The five lots of cheese (control, decoction of chestnut flower, decoction of lemon balm, dried chestnut flowers and dried lemon balm) were labeled, and two samples of each were subjected to immediate analysis (after 1 month maturation), while others were stored at a constant temperature $\left(3.7 \pm 1.6^{\circ} \mathrm{C}\right)$ for 6 months, after which they were analyzed too. All the analysis were carried out in triplicates, and the data were expressed as mean \pm standard deviation, maintaining the decimal places allowed by the magnitude of the standard deviation. An analysis of variance (ANOVA) with type III sums of squares was performed using the GLM (General Linear Model) procedure of the SPSS software. The dependent variables were analyzed using 2-way ANOVA, with the factors "natural additive" (NA) and "storage time" (ST) for each plant species analyzed independently. When a statistically significant interaction $(\mathrm{NA} \times \mathrm{ST})$ was detected, the two factors were evaluated simultaneously by the estimated marginal means plots for all levels of each single factor. Alternatively, if no statistical significant interaction was verified, means were compared using Tukey's honestly significant difference (HSD) multiple comparison test to evaluate the NA effect, or by a $t$-student test to assess the effect of ST.

Besides comparing the effects of different natural additives and storage time for each plant species, the results for all parameters were compared for both plants simultaneously aiming to (i) verify which plant species was the most suitable, independently of using dried plant or decoction, and also to (ii) find which type of natural additive constitute the best solution, independently of the plant species. A stepwise technique, linear discriminant analysis $(L D A)$, using the Wilks' $\lambda$ method with the usual probabilities of $F$ (3.84 to enter and 2.71 to remove), was applied for variable selection. This procedure uses a combination of forward selection and backward elimination procedures, where before selecting a new variable, it is verified whether all variables previously selected remain significant (Palacios-Morillo, Alcázar, Pablos, \& Jurado, 2013). With this approach, it is also possible to identify the significant variables that contribute most to the possible discrimination of a natural additive (dry material or decoction) or plant species (chestnut or lemon balm). To verify which canonical discriminant functions were significant, the Wilks' $\lambda$ test was applied. A leaving-one-out cross-validation procedure was carried out to assess the models performance.

All statistical tests were performed at a $5 \%$ significance level using IBM SPSS Statistics for Windows, version 22.0. (IBM Corp., Armonk, NY, USA).

\section{Results and discussion}

\subsection{Effects on nutritional parameters}

As explained by Carocho, Calhelha, et al. (2014) and Carocho, Barros, et al. (2014) chestnut flowers have excellent antioxidant and antimicrobial capacity, and could be used to functionalize food matrices. (Carocho, Barreira, Antonio, et al., 2015; Carocho, Barreira, et al., 2014). Despite no studies on the incorporation of lemon balm in foods having been previously reported, the antioxidant activity of this plant has also been described by a research group (Carocho, Barros, Calhelha, et al., 2015). Therefore, dried material and lyophilized decoctions of both plant species were used as natural additives in "Serra da Estrela" cheese, in order to evaluate their preserver effects with storage time.

Tables $1-3$ report the proximate composition, mineral composition and fatty acid profile for all the assayed samples, after 1 month of ripening, and after 6 months of maturation. The upper section of each table refers to the dried chestnut flowers and the bottom one to lemon balm. Each of these sections is divided into two parts; natural additive type (NA) (dried plant or decoction) and storage time (ST) (with 1 month and 6 months), both including the control cheese samples (none natural additive). In both cases, the results are presented as the mean value of each NA for both storage times, and also the mean value of ST with all the different natural additives. This approach was used to help identify the optimal ST independently of the natural additive used in the cheese, and also the best natural additive independently of the storage to which the cheese was subject. Thus, the standard deviations should not be regarded as a measure of accuracy of the applied methodologies, since they encompass the results obtained from the samples prepared in different conditions (variation of the non-fixed factor: ST or NA). The interaction between both effects was also evaluated. Every time that a significant interaction was found $(p<0.050)$, no multiple comparisons could be performed. In those cases, the influence of each individual factor was drawn from the estimated marginal means (EMM) plots.

As expected, the samples lost moisture during the 6 months of storage time (as seen in Table 1), which could explain the increase in some components during time. Table 1 reports the proximate composition, and regarding the cheese samples with chestnut flowers, a significant interaction was found for all parameters $(\mathrm{NA} \times \mathrm{ST}<0.05)$, therefore some tendencies were extracted from the EMM plots. Still, regarding the NA, the effect of each individual factor was not significant for moisture, fat, protein and energy, contrary to the observed for the ash content. Furthermore, concerning the ST, the effect of each individual factor was significant for all the parameters. Regarding lemon balm, the behavior was similar to chestnut flowers, with a significant interaction for all the parameters, and tendencies being conveyed through the EMM. These plots showed that moisture decreased in all cheese types after the 6 months of storage, which caused all the other constituents of the cheese to increase. Still, the cheese samples with the natural additives lost a higher quantity of moisture overtime. This is a very interesting feature carried out by the plants, because the decrease of moisture helps preserve the organoleptic and structural shape of the cheese, due to the growth inhibition of proteolytic and other bacteria that cause defect and alterations in cheese, and in some instances can be harmful for consumption (Segat et al., 2014). Furthermore, by decreasing the moisture the contamination risk is lowered, and the cheese can achieve the state of being considered, "old" cheese, faster (very appreciated by consumers, and with a higher value), and therefore reduce the time of ripening needed to achieve this state. A higher amount of proteins was detected in the cheese added with the natural additives 
Table 1

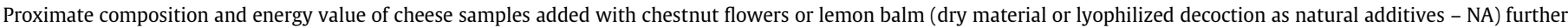
submitted to storage (ST). The results are presented as mean \pm SD.

\begin{tabular}{|c|c|c|c|c|c|c|}
\hline & & Moisture (g/100 g fw) & Fat $(\mathrm{g} / 100 \mathrm{~g} \mathrm{fw})$ & Proteins (g/100 g fw) & Ash (g/100 g fw) & Energy (kcal/100 g fw) \\
\hline \multicolumn{7}{|c|}{ Chestnut flowers } \\
\hline \multirow[t]{4}{*}{ NA } & None & $43 \pm 7$ & $26 \pm 2$ & $33 \pm 4$ & $4 \pm 1$ & $367 \pm 31$ \\
\hline & Dried plant & $39 \pm 11$ & $27 \pm 5$ & $35 \pm 5$ & $4 \pm 1$ & $379 \pm 63$ \\
\hline & Decoction & $40 \pm 10$ & $26 \pm 3$ & $36 \pm 6$ & $5 \pm 1$ & $380 \pm 47$ \\
\hline & $p$-value $(n=18)$ & 0.355 & 0.924 & 0.171 & $<0.001$ & 0.684 \\
\hline \multirow[t]{3}{*}{ ST } & 1 month & $50 \pm 1$ & $23 \pm 1$ & $30 \pm 1$ & $4 \pm 1$ & $330 \pm 13$ \\
\hline & 6 months & $31 \pm 4$ & $29 \pm 1$ & $39 \pm 2$ & $5 \pm 1$ & $420 \pm 19$ \\
\hline & $p$-value $(n=36)$ & $<0.001$ & $<0.001$ & $<0.001$ & $<0.001$ & $<0.001$ \\
\hline $\mathrm{NA} \times \mathrm{ST}$ & $p$-value $(n=72)$ & $<0.001$ & $<0.001$ & $<0.001$ & $<0.001$ & $<0.001$ \\
\hline \multicolumn{7}{|c|}{ Lemon balm } \\
\hline \multirow[t]{4}{*}{ NA } & None & $43 \pm 7$ & $26 \pm 2$ & $33 \pm 4$ & $4 \pm 1$ & $367 \pm 31$ \\
\hline & Dried plant & $38 \pm 10$ & $26 \pm 3$ & $35 \pm 4$ & $5 \pm 1$ & $375 \pm 49$ \\
\hline & Decoction & $43 \pm 6$ & $25 \pm 2$ & $33 \pm 3$ & $5 \pm 1$ & $356 \pm 33$ \\
\hline & $p$-value $(n=18)$ & 0.105 & 0.206 & 0.296 & $<0.001$ & 0.338 \\
\hline \multirow[t]{3}{*}{ ST } & 1 month & $49 \pm 1$ & $23 \pm 1$ & $30 \pm 1$ & $4 \pm 1$ & $330 \pm 7$ \\
\hline & 6 months & $34 \pm 4$ & $28 \pm 1$ & $37 \pm 1$ & $5 \pm 1$ & $402 \pm 16$ \\
\hline & $p$-value $(n=36)$ & $<0.001$ & $<0.001$ & $<0.001$ & $<0.001$ & $<0.001$ \\
\hline $\mathrm{NA} \times \mathrm{ST}$ & $p$-value $(n=72)$ & $<0.001$ & $<0.001$ & $<0.001$ & $<0.001$ & $<0.001$ \\
\hline
\end{tabular}

Table 2

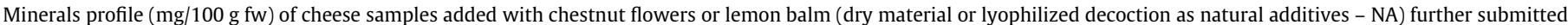
to storage (ST). The results are presented as mean \pm SD.

\begin{tabular}{|c|c|c|c|c|c|c|c|c|}
\hline & & $\mathrm{Ca}$ & $\mathrm{Mg}$ & $\mathrm{Na}$ & K & $\mathrm{Fe}$ & $\mathrm{Zn}$ & $\mathrm{Cu}$ \\
\hline \multicolumn{9}{|c|}{ Chestnut flowers } \\
\hline \multirow[t]{4}{*}{ NA } & None & $987 \pm 158$ & $62 \pm 13$ & $1193 \pm 384$ & $177 \pm 59$ & $0.6 \pm 0.3$ & $6 \pm 1$ & $0.4 \pm 0.1$ \\
\hline & Dried plant & $1289 \pm 149$ & $81 \pm 13$ & $1225 \pm 371$ & $209 \pm 79$ & $1.3 \pm 0.4$ & $7 \pm 1$ & $0.4 \pm 0.1$ \\
\hline & Decoction & $1150 \pm 294$ & $70 \pm 18$ & $1249 \pm 480$ & $174 \pm 80$ & $1.1 \pm 0.1$ & $7 \pm 1$ & $0.3 \pm 0.1$ \\
\hline & $p$-value $(n=18)$ & $<0.001$ & 0.001 & 0.921 & 0.298 & $<0.001$ & $<0.001$ & 0.148 \\
\hline \multirow[t]{3}{*}{ ST } & 1 month & $948 \pm 143$ & $57 \pm 9$ & $823 \pm 36$ & $116 \pm 15$ & $0.9 \pm 0.1$ & $6 \pm 1$ & $0.5 \pm 0.1$ \\
\hline & 6 months & $1335 \pm 142$ & $85 \pm 9$ & $1621 \pm 82$ & $257 \pm 22$ & $1.0 \pm 0.5$ & $7 \pm 1$ & $0.3 \pm 0.1$ \\
\hline & $p$-value $(n=36)$ & $<0.001$ & $<0.001$ & $<0.001$ & $<0.001$ & 0.385 & $<0.001$ & $<0.001$ \\
\hline $\mathrm{NA} \times \mathrm{ST}$ & $p$-value $(n=72)$ & $<0.001$ & $<0.001$ & $<0.001$ & $<0.001$ & $<0.001$ & $<0.001$ & $<0.001$ \\
\hline \multicolumn{9}{|c|}{ Lemon balm } \\
\hline \multirow[t]{4}{*}{ NA } & None & $987 \pm 158$ & $62 \pm 13$ & $1193 \pm 384$ & $177 \pm 59$ & $0.6 \pm 0.3$ & $6 \pm 1$ & $0.4 \pm 0.1$ \\
\hline & Dried plant & $1189 \pm 140$ & $70 \pm 9$ & $1691 \pm 656$ & $205 \pm 71$ & $1.5 \pm 0.5$ & $6 \pm 1$ & $0.2 \pm 0.1$ \\
\hline & Decoction & $958 \pm 117$ & $65 \pm 9$ & $1212 \pm 299$ & $177 \pm 52$ & $1.2 \pm 0.2$ & $5 \pm 1$ & $0.3 \pm 0.1$ \\
\hline & $p$-value $(n=18)$ & $<0.001$ & 0.061 & 0.003 & 0.293 & $<0.001$ & 0.028 & $<0.001$ \\
\hline \multirow[t]{3}{*}{ ST } & 1 months & $921 \pm 97$ & $56 \pm 5$ & $932 \pm 98$ & $127 \pm 7$ & $1.0 \pm 0.1$ & $4 \pm 1$ & $0.4 \pm 0.1$ \\
\hline & 6 months & $1167 \pm 138$ & $76 \pm 3$ & $1799 \pm 384$ & $245 \pm 21$ & $1.2 \pm 0.5$ & $6 \pm 1$ & $0.2 \pm 0.1$ \\
\hline & $p$-value $(n=36)$ & $<0.001$ & $<0.001$ & $<0.001$ & $<0.001$ & 0.115 & $<0.001$ & $<0.001$ \\
\hline $\mathrm{NA} \times \mathrm{ST}$ & $p$-value $(n=72)$ & $<0.001$ & $<0.001$ & $<0.001$ & $<0.001$ & $<0.001$ & $<0.001$ & $<0.001$ \\
\hline
\end{tabular}

(regardless of being with decoction or dried plant), which is an interesting fact. The plants could have inhibited the development of proteolytic bacteria, which reduced the destruction of the protein fraction in the 1 month of ripening. The total fat seemed to be higher after the 6 months of maturation, although appeared to be lower in the cheese with the dried plant incorporated (Fig. 1A-C). This is due to the reduction in moisture over the course of the 6 months, and the fact that the results were expressed in $\mathrm{g} / 100$ of fresh weight.

Table 2 reports the mineral composition of the cheese. Calcium, magnesium, sodium, potassium, iron and copper were the macro and micro minerals detected in the cheese samples. Calcium and sodium were the most abundant minerals, while copper was present in considerably smaller quantities. Once again, for both plants, a significant interaction was detected for all minerals, allowing tendencies to be drawn from the EMM. Regarding cheese samples with chestnut flowers and NA, the effect of each factor was significant for $\mathrm{Ca}, \mathrm{Mg}$, Fe and $\mathrm{Zn}$, although Fe was the only mineral where both factors were not significant, with regards to ST. The same behavior was reported for lemon balm. Some minerals seemed to duplicate over time, but this could be explained by the loss of moisture of all the cheeses during storage, aiding to the sensibility of the method and the statistical treatment. The EMM plots show that the cheese with the decoctions incorporated showed more sodium after 6 months, but the cheese with the dried plant had less calcium in the beginning of the storage period (Fig. 1D and E).

Table 3 reports the detected individual fatty acids and the total percentages of saturated fatty acids (SFA), monounsaturated fatty acids (MUFA) and polyunsaturated fatty acids (PUFA). The most abundant fatty acids in the cheese samples were $\mathrm{C} 18: 1$ and C16:0, and the SFA prevailed over the MUFA, with PUFA being the least abundant. Regarding cheese samples with chestnut flow- 
Table 3

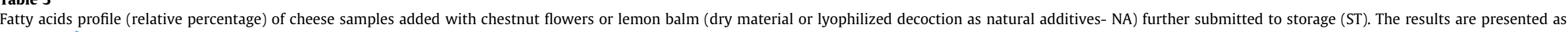
mean \pm SD.

\begin{tabular}{|c|c|c|c|c|c|c|c|c|c|c|c|c|c|c|c|c|c|c|}
\hline & & $\mathrm{C} 4: 0$ & C6:0 & C8:0 & C10:0 & C12:0 & C14:0 & $\mathrm{C} 15: 0$ & C16:0 & C16:1 & $\mathrm{C} 17: 0$ & C18:0 & C18:1 & C18:2 & $\mathrm{C} 18: 3$ & SFA & MUFA & PUFA \\
\hline \multicolumn{19}{|c|}{ Chestnut flowers } \\
\hline \multirow[t]{4}{*}{ NA } & None & $2.3 \pm 0.1$ & $2.6 \pm 0.2$ & $2.6 \pm 0.3$ & $8 \pm 1 \mathrm{ab}$ & $5 \pm 1$ & $11 \pm 1$ & $1.4 \pm 0.2$ & $25 \pm 2$ & $1.0 \pm 0.1$ & $1.0 \pm 0.1$ & $11 \pm 1 \mathrm{a}$ & $23 \pm 4$ & $2.1 \pm 0.4$ & $1.8 \pm 0.2$ & $71 \pm 4$ & $24 \pm 3$ & $4.8 \pm 0.5$ \\
\hline & Dried plant & $2.0 \pm 0.1$ & $2.3 \pm 0.2$ & $2.3 \pm 0.2$ & $7 \pm 1 \mathrm{~b}$ & $5 \pm 1$ & $11 \pm 1$ & $1.5 \pm 0.2$ & $26 \pm 2$ & $0.9 \pm 0.1$ & $1.1 \pm 0.1$ & $11 \pm 1 \mathrm{a}$ & $24 \pm 4$ & $2.2 \pm 0.4$ & $1.8 \pm 0.1$ & $70 \pm 4$ & $25 \pm 4$ & $4.9 \pm 0.5$ \\
\hline & Decoction & $3.0 \pm 0.1$ & $2.9 \pm 0.2$ & $2.9 \pm 0.4$ & $8 \pm 1 \mathrm{a}$ & $5 \pm 1$ & $11 \pm 1$ & $1.4 \pm 0.2$ & $25 \pm 1$ & $0.9 \pm 0.1$ & $1.1 \pm 0.1$ & $10 \pm 1 \mathrm{~b}$ & $22 \pm 4$ & $2.2 \pm 0.2$ & $1.7 \pm 0.2$ & $72 \pm 4$ & $23 \pm 3$ & $4.6 \pm 0.5$ \\
\hline & $p$-value $(n=18)$ & $<0.001$ & $<0.001$ & $<0.001$ & 0.002 & 0.266 & 0.912 & 0.901 & 0.178 & 0.098 & 0.407 & $<0.001$ & 0.612 & 0.825 & 0.088 & 0.522 & 0.576 & 0.264 \\
\hline \multirow[t]{3}{*}{ ST } & 1 month & $2.3 \pm 0.2$ & $2.5 \pm 0.2$ & $2.4 \pm 0.2$ & $7 \pm 1$ & $4.3 \pm 0.3$ & $10.6 \pm 0.4$ & $1.3 \pm 0.1$ & $24 \pm 1$ & $0.9 \pm 0.1$ & $1.0 \pm 0.1$ & $11 \pm 1$ & $26 \pm 1$ & $2.5 \pm 0.2$ & $1.9 \pm 0.1$ & $67 \pm 1$ & $28 \pm 1$ & $5.3 \pm 0.3$ \\
\hline & 6 months & $2.4 \pm 0.4$ & $2.6 \pm 0.4$ & $2.9 \pm 0.4$ & $9 \pm 1$ & $5.6 \pm 0.3$ & $12.5 \pm 0.4$ & $1.6 \pm 0.1$ & $27 \pm 1$ & $1.0 \pm 0.1$ & $1.1 \pm 0.1$ & $10 \pm 1$ & $19 \pm 1$ & $1.9 \pm 0.2$ & $1.7 \pm 0.2$ & $75 \pm 1$ & $21 \pm 1$ & $4.3 \pm 0.2$ \\
\hline & $p$-value $(n=36)$ & 0.086 & 0.249 & $<0.001$ & $<0.001$ & $<0.001$ & $<0.001$ & $<0.001$ & $<0.001$ & $<0.001$ & $<0.001$ & $<0.001$ & $<0.001$ & $<0.001$ & $<0.001$ & $<0.001$ & $<0.001$ & $<0.001$ \\
\hline $\mathrm{NA} \times \mathrm{ST}$ & $p$-value $(n=72)$ & $<0.001$ & 0.001 & 0.001 & 0.244 & 0.553 & 0.009 & 0.199 & 0.003 & 0.040 & $<0.001$ & 0.215 & 0.785 & $<0.001$ & 0.611 & 0.835 & 0.999 & 0.170 \\
\hline \multicolumn{19}{|c|}{ Lemon balm } \\
\hline \multirow[t]{4}{*}{ NA } & None & $2.3 \pm 0.1$ & $2.6 \pm 0.2$ & $2.6 \pm 0.3$ & $8 \pm 1$ & $5 \pm 1$ & $11 \pm 1$ & $1.4 \pm 0.2$ & $25 \pm 2$ & $1.0 \pm 0.1 \mathrm{a}$ & $1.0 \pm 0.1$ & $11 \pm 1$ & $23 \pm 4$ & $2.1 \pm 0.4$ & $1.8 \pm 0.2$ & $71 \pm 4$ & $24 \pm 3$ & $4.8 \pm 0.5$ \\
\hline & Dried plant & $2.0 \pm 0.2$ & $2.3 \pm 0.3$ & $2.3 \pm 0.2$ & $7 \pm 1$ & $5 \pm 1$ & $11 \pm 1$ & $1.5 \pm 0.2$ & $26 \pm 2$ & $1.0 \pm 0.1 \mathrm{a}$ & $1.1 \pm 0.2$ & $11 \pm 1$ & $24 \pm 4$ & $2.1 \pm 0.4$ & $1.9 \pm 0.2$ & $70 \pm 5$ & $25 \pm 4$ & $4.8 \pm 0.5$ \\
\hline & Decoction & $2.6 \pm 0.5$ & $2.7 \pm 0.5$ & $2.8 \pm 0.5$ & $8 \pm 1$ & $5 \pm 1$ & $11 \pm 1$ & $1.4 \pm 0.2$ & $25 \pm 1$ & $0.9 \pm 0.1 \mathrm{~b}$ & $1.0 \pm 0.1$ & $11 \pm 1$ & $23 \pm 5$ & $2.3 \pm 0.3$ & $1.8 \pm 0.2$ & $71 \pm 5$ & $24 \pm 5$ & $4.8 \pm 0.5$ \\
\hline & $p$-value $(n=18)$ & $<0.001$ & 0.003 & 0.006 & 0.133 & 0.974 & 0.783 & 0.426 & 0.249 & 0.001 & 0.078 & 0.250 & 0.735 & 0.584 & 0.334 & 0.771 & 0.716 & 0.991 \\
\hline \multirow[t]{3}{*}{ ST } & 1 month & $2.1 \pm 0.2$ & $2.4 \pm 0.2$ & $2.3 \pm 0.2$ & $6 \pm 1$ & $4.2 \pm 0.3$ & $10.5 \pm 0.4$ & $1.3 \pm 0.1$ & $24 \pm 1$ & $0.9 \pm 0.1$ & $1.0 \pm 0.1$ & $11 \pm 1$ & $27 \pm 1$ & $2.6 \pm 0.2$ & $2.0 \pm 0.2$ & $66 \pm 1$ & $28 \pm 1$ & $5.4 \pm 0.3$ \\
\hline & 6 months & $2.5 \pm 0.5$ & $2.6 \pm 0.4$ & $2.9 \pm 0.4$ & $8 \pm 1$ & $5.6 \pm 0.3$ & $12.5 \pm 0.4$ & $1.6 \pm 0.1$ & $27 \pm 1$ & $1.0 \pm 0.1$ & $1.1 \pm 0.1$ & $10 \pm 1$ & $19 \pm 1$ & $1.8 \pm 0.2$ & $1.7 \pm 0.2$ & $75 \pm 1$ & $21 \pm 1$ & $4.2 \pm 0.2$ \\
\hline & $p$-value $(n=36)$ & 0.001 & 0.053 & $<0.001$ & $<0.001$ & $<0.001$ & $<0.001$ & $<0.001$ & $<0.001$ & $<0.001$ & 0.001 & $<0.001$ & $<0.001$ & $<0.001$ & $<0.001$ & $<0.001$ & $<0.001$ & $<0.001$ \\
\hline $\mathrm{NA} \times \mathrm{ST}$ & $p$-value $(n=72)$ & $<0.001$ & $<0.001$ & $<0.001$ & $<0.001$ & 0.010 & 0.044 & 0.439 & $<0.001$ & 0.191 & $<0.001$ & $<0.001$ & $<0.001$ & 0.093 & 0.433 & $<0.001$ & $<0.001$ & 0.009 \\
\hline
\end{tabular}

" Means within a column with different letters differ significantly $(p<0.05)$. 

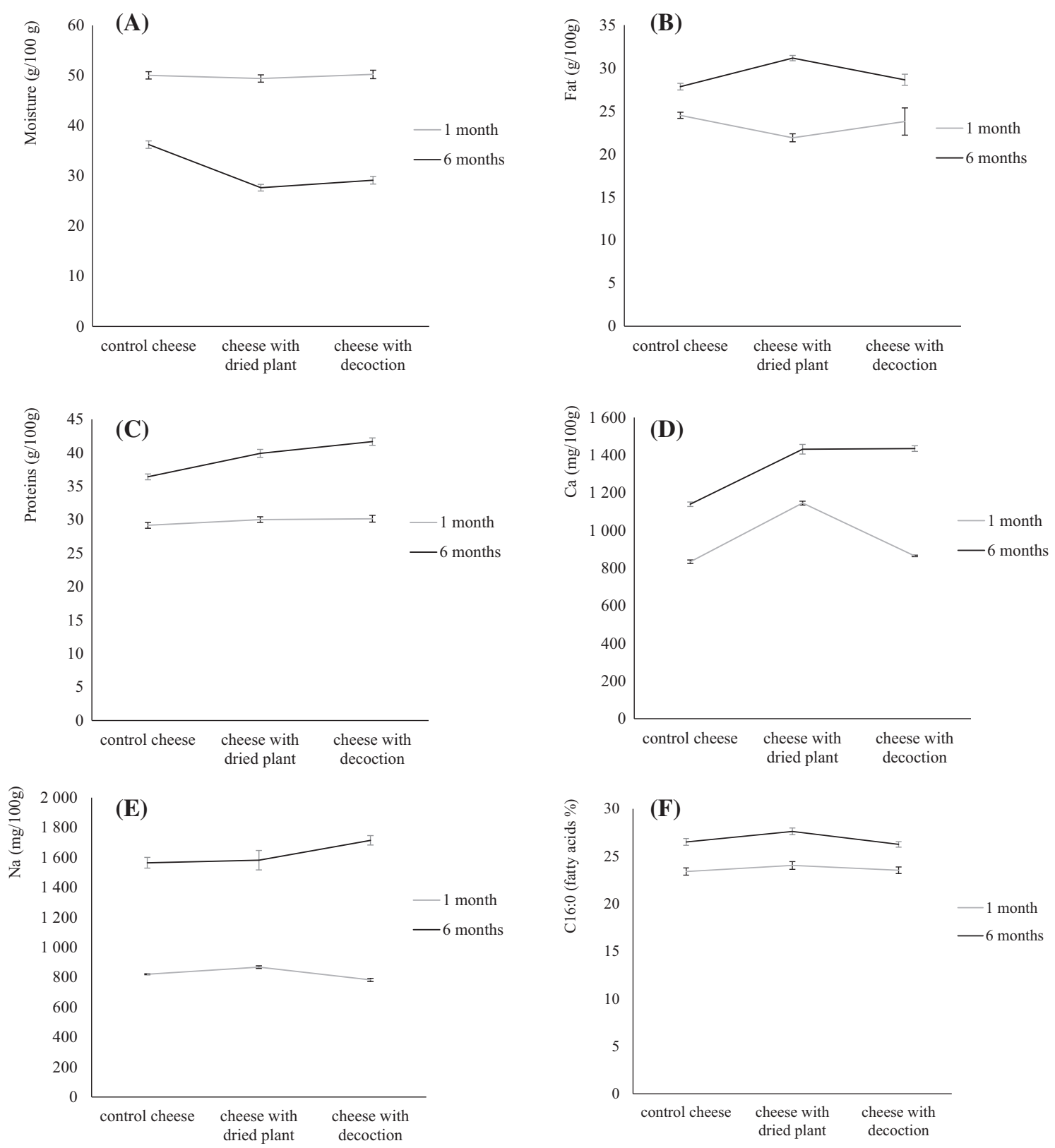

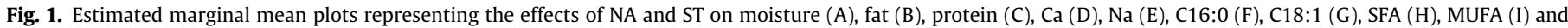
PUFA (J).

ers, significant interactions were detected for C4:0, C6:0, C8:0, $\mathrm{C} 14: 0, \mathrm{C} 16: 0 \mathrm{C} 16: 1, \mathrm{C} 17: 0$ and $\mathrm{C} 18: 2$, therefore, some tendencies were retrieved from the EMM plots. Regarding NA, they had significant interactions for C12:0, C14:0, C15:0, C16:0, C16:1, C17:0, C18:1, C18:2, SFA, MUFA and PUFA, while ST was only significant for $C 4: 0$ and $C 6: 0$. For the cheese samples added with lemon balm, significant interactions were detected for C10:0, C12:0, C14:0, C15:0, C16:0, C17:0, C18:1, C18:2, C18:3, SFA, MUFA and PUFA, while ST was only significant for C6:0. It is noticeable that the use of decoctions and dried plants as natural additives had higher effects on the fatty acids profile than the storage time. The EMM plots revealed that C16:0 and SFA showed very little change among the different cheese types, while C18:1 was more abundant in the cheese samples with the dried plants. Considering that this fatty acid is a monounsaturated molecule, and one of the most abundant ones in this cheese, its conservation over the 6 months is desirable. The cheese samples with the decoctions seemed to show less
MUFA, while the ones with the dried plants had more, once again these molecules were preserved by the dried plants, which proves their efficacy as preservatives, promoting the beneficial effects of these unsaturated molecules. In terms of PUFA, the cheese with dried plants incorporated showed more at 1 month. There was very little change in these fatty acids during the storage period. Given that this is the least abundant fraction of fatty acids, with only two significant molecules, it was expected that very slight changes would be detected (Fig. 1F-J).

\subsection{Linear discriminant analysis (LDA)}

In the former section, the alterations resulting from the incorporation of chestnut flowers or lemon balm, either as dried plant or decoction, in "Serra da Estrela" cheese were analyzed parameter by parameter, considering each species individually. Despite different significant variations, the identification of explicit tendencies is 

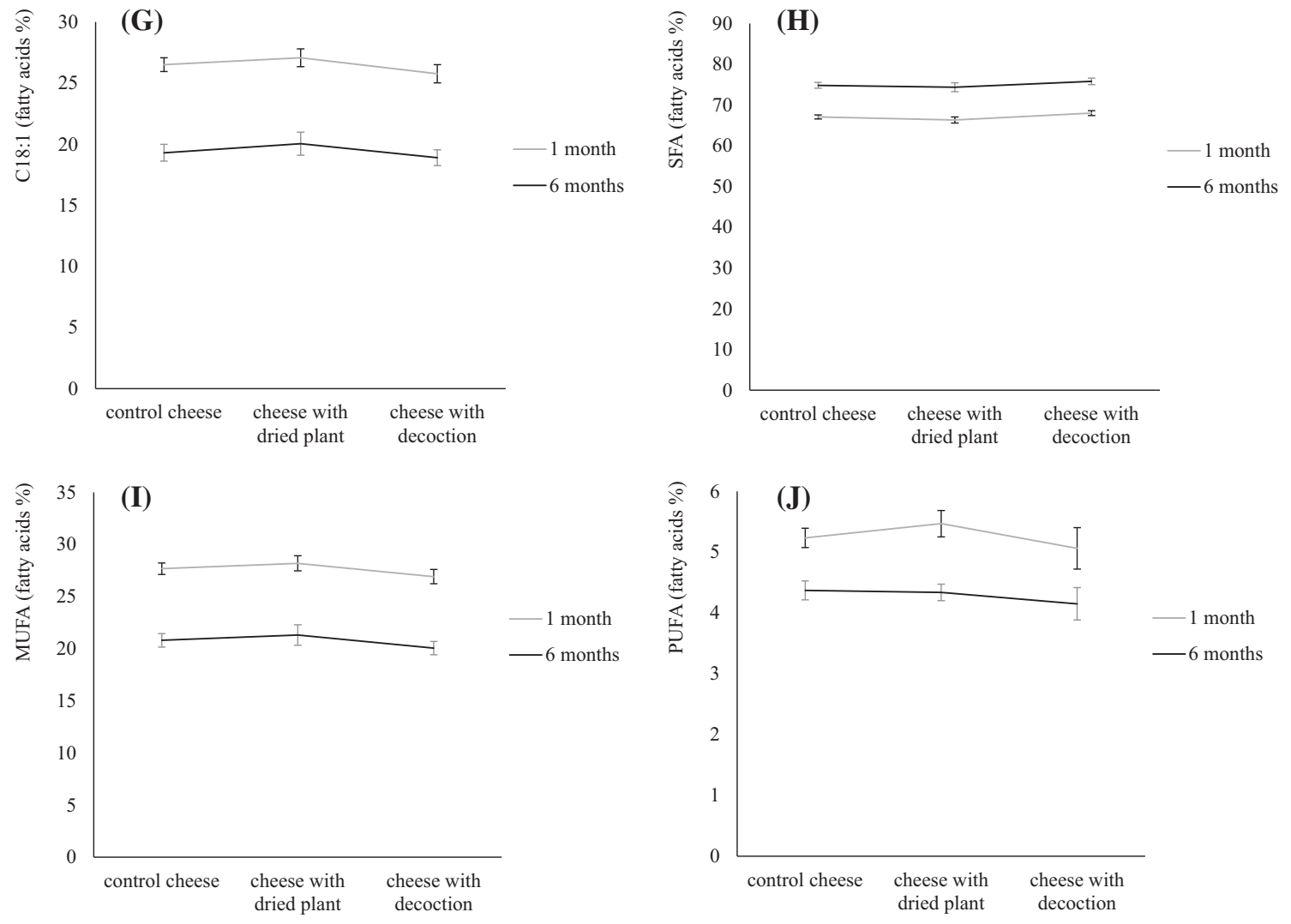

Fig. 1 (continued)

easier when all the parameters are evaluated simultaneously, including data for both species or for all natural additive type. Accordingly, two distinct linear discriminant analysis (LDA) were applied, where "plant species" and "natural additive type" were sequentially used as grouping factors. The significant independent variables (evaluated parameters) were selected using the stepwise procedure of the LDA, according to the Wilks' $\lambda$ test. Only those with a statistical significant classification performance $(p<0.050)$ were kept in the analysis.

In the discriminant model designed to verify if the plant species (none, chestnut and lemon balm) had an overall influence in the evaluated parameters, the defined functions (plotted in Fig. 2) integrated $100 \%$ of the observed variance (first: $57.3 \%$; second: $42.7 \%$ ). Among the tested variables, those selected as having discriminant ability were moisture, fat, protein, ash, $\mathrm{Fe}, \mathrm{Mg}, \mathrm{K}, \mathrm{Cu}, \mathrm{Zn}, \mathrm{C18}: 0$, $\mathrm{C} 20: 3, \mathrm{C} 22: 0, \mathrm{C} 22: 6, \mathrm{C} 23: 0$ and C24:0, which indicates they are the most affected variables in function of the used plant species. Function 1 (more correlated with $\mathrm{C} 22: 0, \mathrm{Cu}, \mathrm{Zn}$ and ash) separated mainly the group corresponding to cheese samples with lemon balm; function 2 (more correlated with Fe, C20:3, C22:6, Mg and $\mathrm{C} 24: 0)$, on the other hand, separated mainly samples with chestnut flowers and control samples.

Regarding the effects of functionalizing type (independently of the plans species), the defined functions also included $100 \%$ of the observed variance (first: $74.6 \%$; second: $25.4 \%$ ), selecting moisture, fat, energy, Fe, Mg, Zn, Ca, K, C11:0, C13:0, C18:1, C18:2, $\mathrm{C} 22: 6, \mathrm{C} 24: 0$ and SFA as the significant discriminant variables. The markers corresponding to each functionalizing type were completely separated (Fig. 3). Regarding the variables more correlated to function 1 ( $\mathrm{Fe}, \mathrm{C} 22: 6$, $\mathrm{Ca}$ and $\mathrm{Mg}$ ), samples corresponding to the decoctions showed higher similarity to the control than the dried samples; on the other hand, dried samples were closer to the con- trol samples for the variables more correlated to function 2 (C24:0, C11:0 and C13:0).

\section{Conclusion}

When analyzed individually, the parameters reported herein showed some significant changes among control cheese and that added with dried plants or their decoctions (natural additives). Furthermore, there were evident changes among the initial stage and the end of maturation. The moisture loss was higher overtime in the samples with the plants incorporated, with a higher prevalence in the dried flowers. This increased the amount of the other parameters after the 6 months. The loss of water was desired, in order to decrease contamination probability and the proliferation of proteolytic bacteria, helping maintain the protein fraction of the cheese. In this particular type of cheese, maturated cheese is also very appreciated and bought at a higher price. By losing a higher quantity of moisture, the maturing could be significantly reduced. Furthermore, due to the loss of moisture, all other analyzed parameters seemed to have increased overtime, which was expected. Overall, the direct incorporation of dried plants (lemon balm or chestnut flowers) seemed to be a better alternative to the decoctions. The dried plants ensured a higher loss of moisture, lower calcium and sodium, higher preservation of the most abundant MUFA (C18:1) and higher quantity of PUFA (after 1 month). The decoctions, seemed to preserve the proteins in both of the analyzed times. Although the preservation of proteins is very important for the organoleptic interest, the decoctions fall close behind of the preservations aspects of the dried plants, although quite better than the control samples. In certain cases, the color and taste of the cheeses could be changed by incorporation of the dried plants, 


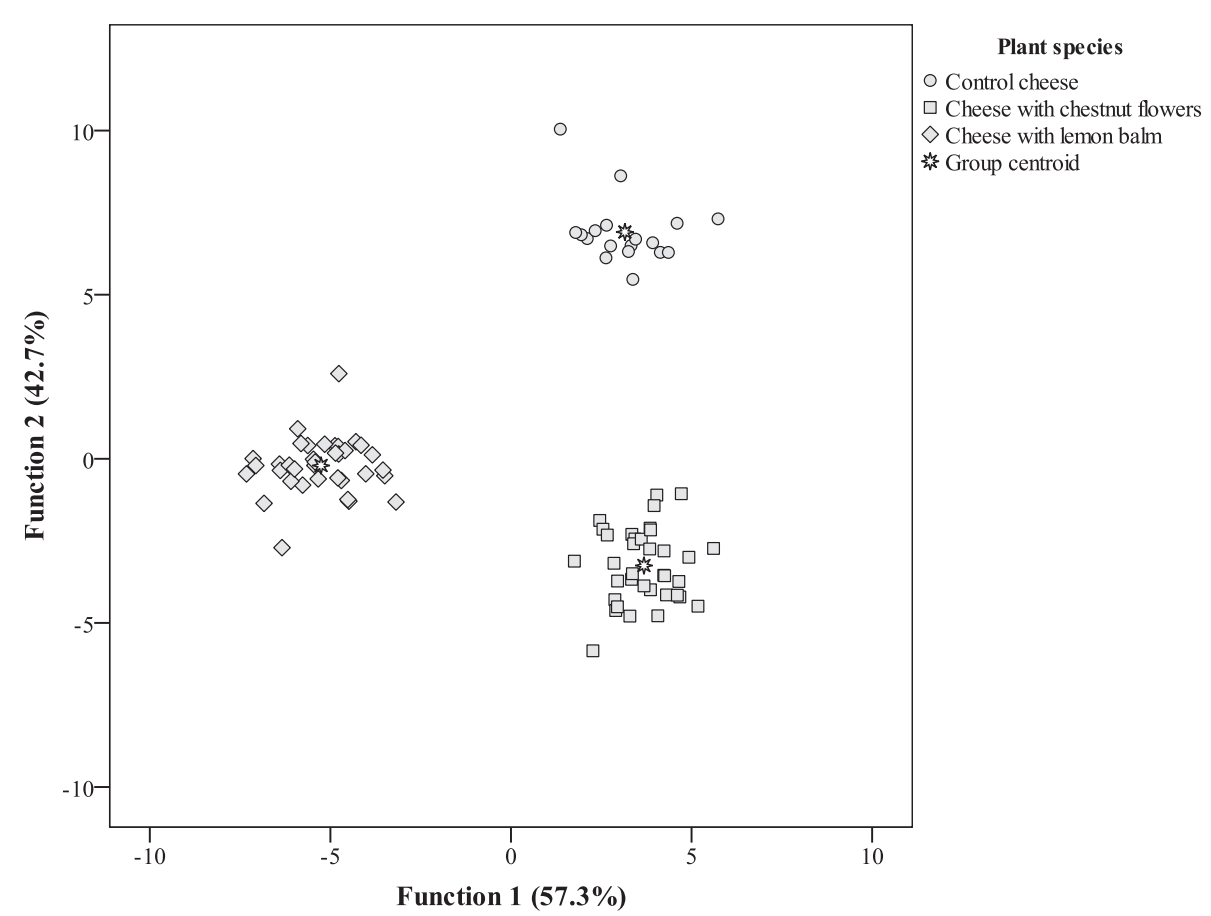

Fig. 2. Mean scores of cheese samples with plant species projected for the two discriminant functions defined from all evaluated parameters.

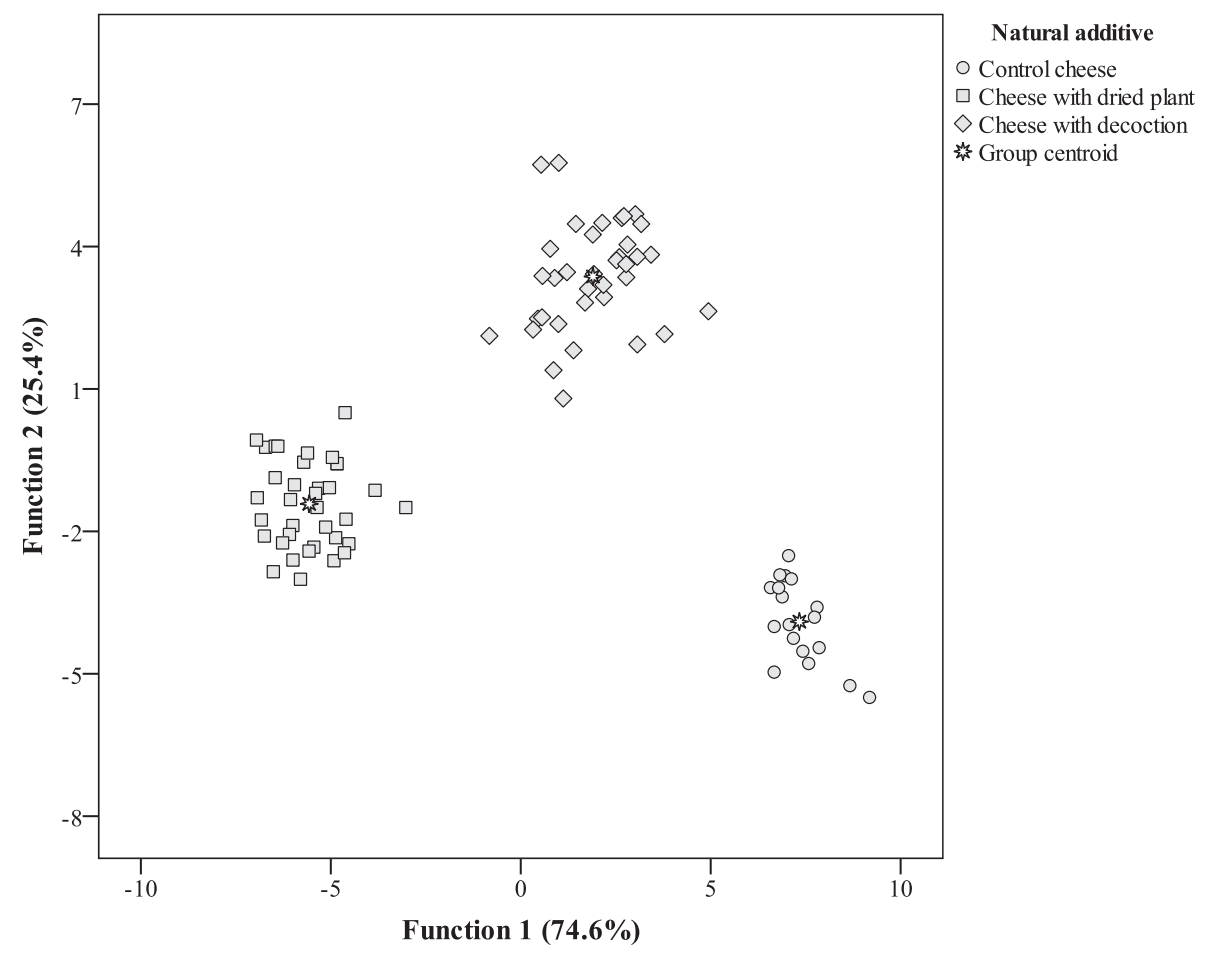

Fig. 3. Mean scores of cheese samples with natural additive type projected for the two discriminant functions defined from all evaluated parameters.

and therefore become less appealing to certain customers, while the incorporation of the decoctions went undetected. These conclusions are quite interesting, for one, the dried plants could be preserving agents while also lending taste and a different appearance to the cheese, which could interest some consumers but discourage others. On the other hand, the decoctions, although not so strong in the preserving area, could still carry this out while not changing the overall taste and appearance of the cheese. Some gen- eral conclusions were achieved through the performed LDA, which show the plant species (independently of natural additive type) and the natural additive type (independently of plant species) that better maintained the measured parameters in the control samples. By evaluating the produced outcomes, especially considering the correlations among selected variables and discriminant functions, it is also possible to suggest the best conditions to be applied in order to obtain a determined profile in the maturated "Serra da 
Estrela" cheese. Overall, the dried plant incorporations had higher preserving capacity when compared to the decoctions, but they also alter the appearance of the cheese. Thus, the decoctions, although slightly inferior in terms of preservations (only better for protein preservation) could also be good candidates for this functions due to not altering the appearance of cheese. Still, in terms of promoting differentiated foods (different colors and tastes), the dried plants proved to be better.

\section{Conflict of interest}

The authors state that there is no conflict of interest regarding this manuscript.

\section{Acknowledgments}

The authors are grateful to Queijos Casa Matias, Lda and Mais Ervas, Lda. For providing the cheese and $M$. officinalis samples, respectively. The authors also acknowledge PRODER project No. 46577-PlantLact, the Foundation for Science and Technology (FCT, Portugal) for financial support to the CIMO research centre (Pest-OE/AGR/UI0690/2014) and ALIMNOVA research group (UCM-951505/2012), J.C.M. Barreira acknowledges the FCT for his post-doctoral grant (BPD/72802/2010).

\section{References}

AOAC (2012). Official methods of analysis of AOAC International (19th ed.). . Gaithersburg, MD, USA.

Barros, L., Oliveira, S., Carvalho, A. M., \& Ferreira, I. C. F. R. (2010). In vitro antioxidant properties and characterization in nutrients and phytochemicals of six medicinal plants from the Portuguese folk medicine. Industrial Crops and Products, 32, 572-579.

Barros, L., Dueñas, M., Dias, M. I., Sousa, M. J., Santos-Buelga, C., \& Ferreira, I. C. F. R. (2013). Phenolic profiles of cultivated, in vitro cultured and commercial samples of Melissa officinalis L. infusions. Food Chemistry, 136, 1-8.

Carnat, A. P., Carnat, A., Fraisse, D. \& Lamaison, J. L. (1998). The aromatic and polyphenolic composition of lemon balm (Melissa officinalis L. subsp. officinalis) tea. Pharmaceutica Acta Helvetiae, 72, 301-305.

Carocho, M., Barreiro, M. F., Morales, P., \& Ferreira, I. C. F. R. (2014a). Adding molecules to food, pros and cons: A review on synthetic and natural food additives. Comprehensive Reviews in Food Science and Food Safety, 13, 377-399.

Carocho, M., Calhelha, R. C., Queiroz, M. R. P., Bento, A., Morales, P., Soković, M., \& Ferreira, I. C. F. R. (2014b). Infusions and decoction of Castanea sativa flowers as effective antitumor and antimicrobial matrices. Industrial Crops and Products, 62, 42-46.

Carocho, M., Barros, L., Bento, A., Santos-Buelga, C., Morales, P., \& Ferreira, I. C. F. R. (2014c). Castanea sativa Mill. flowers amongst the most powerful antioxidants: A phytochemical approach in decoctions and infusions. BioMed Research International. 7 pages 232956.

Carocho, M., Barreira, J. C. M., Bento, A., Morales, P., \& Ferreira, I. C. F. R. (2014d). Chestnut flowers as functionalizing agents to enhance the antioxidant properties of highly appreciated traditional pastry. Food E Function, 5, 2989-2995.

Carocho, M., Barros, L., Calhelha, R. C., Soković Santos-Buelga, C., Morales, P., \& Ferreira, I. C. F. R. (2015a). Melissa officinalis L. decoctions as functional beverages: A bioactive approach and chemical characterization. Food $\mathcal{\sigma}$ Function, 6, 2240-2248.

Carocho, M., Morales, P., \& Ferreira, I. C. F. R. (2015b). Natural Food additives. Quo vadis? Trends in Food Science \& Technology, 45, 284-295.

Carocho, M., Barreira, J. C. M., Barros, L., Bento, A., Cámara, M., Morales, P., \& Ferreira, I. C. F. R. (2015c). Traditional pastry with chestnut flowers as natural ingredients: An approach of the effects on nutritional value and chemical composition. Journal of Food Composition and Analysis, 44, 93-101.

Carocho, M., Barreira, J. C. M., Antonio, A. L., Bento, A., Morales, P., \& Ferreira, I. C. F. R. (2015d). The incorporation of plant materials in "Serra da Estrela" cheese improves antioxidant activity without changing fatty acids profile and visual appearance. European Journal of Lipid Science and Technology, 117, 1607-1614.

Dahl, S., Tavaria, F. K., \& Malcata, F. X. (2000). Relationships between flavour and microbiological profiles in Serra da Estrela cheese throughout ripening. International Dairy Journal, 10, 255-262.

Fernández-Ruiz, V., Olives, A. I., Cámara, M., Sánchez-Mata, M. C., \& Torija, M. E. (2011). Mineral and trace elements content in 30 accessions of tomato fruits (Solanum lycopersicum L.), and wild relatives (Solanum pimpinellifolium L., Solanum cheesmaniae L. Riley, and Solanum habrochaites S. Knapp \& D.M. Spooner). Biological Trace Element Research, 141, 329-339.

Macedo, A. C., Tavares, T. G., \& Malcata, F. X. (2004). Influence of native lactic acid bacteria on the microbiological, biochemical and sensory profiles of Serra da Estrela cheese. Food Microbiology, 21, 233-240.

Martins, E. N., Pessano, N. T. C., Leal, L., Roos, D. H., Folmer, V., Puntel, G. O., ... Puntel, R. L. (2012). Protective effect of Melissa officinalis aqueous extract against Mninduced oxidative stress in chronically exposed mice. Brain Research Bulletin, 87, 74-79.

McCarthy, T. L., Kerry, J. P., Kerry, J. F., Lynch, P. B., \& Buckey, D. J. (2001). Evaluation of the antioxidant potential of natural food/plant extracts as compared with synthetic antioxidants and vitamin $\mathrm{E}$ in raw and cooked pork patties. Meat Science, 58, 45-52.

Mlcek, J., \& Rop, O. (2011). Fresh edible flowers of ornamental plants - A new source of nutraceutical foods. Trends in Food Science \& Technology, 22, 561-569.

Neves, J. M., Matos, C., Moutinho, C., Queiroz, G., \& Gomes, L. R. (2009). Ethopharmacological notes about ancient uses of medicinal plants in Trás-osMontes (northern of Portugal). Journal of Ethnopharmacology, 124, 270-283.

Palacios-Morillo, A., Alcázar, Á., Pablos, F., \& Jurado, J. M. (2013). Differentiation of tea varieties using UV-vis spectra and pattern recognition techniques. Spectrochimica Acta Part A: Molecular and Biomolecular Spectroscopy, 103, 79-83.

Partidário, A. M., Barbosa, B., \& Boas, L. V. (1998). Free fatty acids, triglycerides and volatile compounds in Serra da Estrela cheese - Changes throughout ripening. International Dairy Journal, 8, 873-881.

Pereira, R. P., Bolignon, A. A., Appel, A. S., Fachinetto, R., Ceron, C. S., Tanus-Santos, J. E., ... Rocha, J. B. T. (2014). Chemical composition, antioxidant and anticholinesterase activity of Melissa officinalis. Industrial Crops and Products, $53,34-45$.

Reihani, S. F. S., Tan, T., Huda, N., \& Easa, A. M. (2014). Frozen storage stability of beef patties incorporated with extracts from ulam raja leaves (Cosmos caudatus). Food Chemistry, 155, 17-23.

Salah, S. M., \& Jäger, A. K. (2005). Screening of traditionally used Lebanese herbs for neurological activities. Journal of Ethnopharmacology, 97, 145-149.

Segat, A., Biasutti, M., Iacumin, L., Comi, G., Baruzzi, F., Carboni, C., \& Innocente, N. (2014). Use of ozone in production chain of high moisture Mozzarella cheese. LWT - Food Science and Technology, 55, 513-520.

Stojković, D. S., Živković, J., Soković, M., Glamočlija, J., Ferreira, I. C. F. R., Janković, T. \& Maksimović, Z. (2013). Antibacterial activity of Veronica montana L. extract and of protocatechuic acid incorporated in a food system. Food and Chemical Toxicology, 55, 209-213.

Tavaria, F. K., Franco, I., Carballo, F. J., \& Malcata, F. X. (2003). Amino acid and soluble nitrogen evolution throughout ripening of Serra da Estrela cheese. International Diary Journal, 13, 537-545.

Tavaria, F. K., Reis, P. J. M., \& Malcata, F. X. (2006). Effect of dairy farm and milk refrigeration on microbiological and microstructural characteristics of matured Serra da Estrela cheese. International Dairy Journal, 16, 895-902. 